UDC 94 (477.83)(092): 930.25:636

DOI: $10.24919 / 2519-058 \times .12 .177564$

Volodymyr SHULHA

Doctoral Candidate (Hystory) of National Scientific Agricultural Library of NAAS, PhD (Geography),10 Heroiv Oborony Street, Kyiv, Ukraine, postal code 03127 (shulhavp@online.ua)

ORCID: http://orcid.org/0000-0001-9389-6691

ResearcherID: C-7262-2019 (http:/www.researcherid.com/rid/C-7262-2019)

\title{
Володимир ШУЛЬГА
}

докторант-історик Національної наукової сільськогосподарської бібліотеки НААН, кандидат географічних наук, вул. Героїв Оборони, 10, Київ, Украӥна, індекс 03127 (shulhavp@online.ua)

Бібліографічний опис статті: Shulha, V. (2019). Ukrainian Economic Academy (1922 - 1935) as a model of development of agrarian education and science by Ukrainian diaspory. Skhidnoievropeiskyi Istorychnyi Visnyk [East European Historical Bulletin], 12, 108-115. doi: 10.24919/2519-058x.12.177564

\section{UKRAINIAN ECONOMIC ACADEMY (1922 - 1935) AS A MODEL OF DEVELOPMENT OF AGRARIAN EDUCATION AND SCIENCE BY UKRAINIAN DIASPORY}

Summary. The aim of research is to highlight the main stages of organization Ukrainian Economic Academy (Podebrady, Czechoslovakia), its activities, structure and contribution to the development of agricultural science. The research methodology is based on the general scientific principles of historical authenticity, objectivity, systemicity, complexity, and scientific. The author used general scientific, interdisciplinary and special historical methods. The article is based on factual material, archival documents, which reveal the history of creation of the Ukrainian Economic Academy, as the higher school of the polytechnic type, functioning on the traditions of the Ukrainian free science, culture and patriotism. The scientific novelty of the article is that the author first demonstrated a difficult period of formation, reform and development of Academy, which received a good material and technical base, qualified teaching staff, a significant number of students have achieved positive results in the preparation of highly educated professionals. Academy has become an essential element of the spiritual unity of Ukrainians, an indicator of the maturity of the Ukrainian science, education and culture. Conclusions. The representatives of Academy considered knowledge as a factor of socio-economic welfare of the people and confirmed the tendency of increased influence of scientific-educational and cultural potential for the deepening and affirmation of national consciousness, social organization and activities of Ukrainians in the deployment of the struggle for independence of their homeland. The education of future specialists was aimed at rebuilding the national economy and a new Ukrainian state, serving the interests of the nation and society. Democratic methods of the Academy's activities, the use of the latest advances in science and technology contributed to its mutually beneficial cooperation with various scientific organizations in Europe and America. This ensured the effectiveness of the Academy, in particular, the high level of teaching, which, by their knowledge and skills, did not yield to graduates of the universities of the West, successfully worked in various fields of the economy. Achievements of the educational complex increased its authority on the international arena and showed that Ukrainian science abroad occupied an honorable place.

Key words: Ukrainian Economic Academy, academic staff, student community, the learning process, scientific researches. 


\title{
УКРАЇНСЬКА ГОСПОДАРСЬКА АКАДЕМІЯ (1922 - 1935) ЯК МОДЕЛЬ РОЗВИТКУ АГРАРНОЇ ОСВІТИ ТА НАУКИ УКРАЇНСЬКОЮ ДІАСПОРОЮ
}

\begin{abstract}
Анотація. Метою статті є висвітлення основних етапів організації Української господарської академії (Подебради, Чехословаччина), ї̈ діяльності, структури та внеску в розвиток аграрної науки. Методологія дослідження трунтується на загальнонаукових принципах історичної достовірності, об'єктивності, системності, комплексності і науковості. Автор використав загальнонаукові, міждисииплінарні та спеціальні історичні методи. Стаття базується на фактичному матеріалі, архівних документах, які розкривають історію створення Украӥнської господарської академії як вищої школи політехнічного типу, що діяла за традиціями украӥнської вільної науки, культури і патріотизму. Наукова новизна статті полягає у тому, що автор уперше продемонстрував складний період становлення, реформування та розвитку Академії, яка, отримавщи відповідну матеріально-технічну базу, кваліфікований викладацький склад, значну кількість студентів, досягла позитивного результату в підготовиі високоосвічених фахівиів. Академія набула значення істотного елемента духовної єдності украӥнців, показника зрілості украйнської науки, освіти і культури. Висновки. Представники Академї̈ розглядали знання як чинник сочіально-економічного благополуччя і підтвердили тенденцію посилення впливу науково-освітнього та культурного потенціалу на поглиблення й утвердження національної свідомості, сочіальної організації і діяльності украӥнців у розгортанні боротьби за незалежність своєї батьківщини. Освіта майбутніх фахівців була спрямована на відбудову національної економіки i нової української держави, служила інтересам наиії і суспільства. Демократичні методи діяльності Академії, використання новітніх досягнень науки і техніки сприяли ї̈ взаємовигідній співпраці з різними науковими організаціями Свропи й Америки. Це забезпечувало ефективність діяльності Академії, зокрема високий рівень підготовки кадрів, які за своїми знаннями та вміннями не поступалися випускникам університетів країн Заходу, успішно праџювали в різних галузях економіки. Досягнення навчально-наукового комплексу підвищували його авторитет на міжнародній арені $і$ засвідчували, що українська наука за кордоном займала почесне місие.

Ключові слова: Українська господарська академія, викладачі, студентська спільнота, навчальний прочес, наукові дослідження
\end{abstract}

The problem statement. Ukrainian educational and scientific complex in Czechoslovakia followed the principles of democratic governance by the Academy, wide scientific training of students, promotion of self-education, studying the best world literature on various subjects, a combination of scientific and theoretical knowledge of production practices and seminars. Scientists of the Academy maintained close relations with international organizations involved in international scientific forums were recognizing the world scientific community, indicating the maturity of emigrant branch high school. The Academy has made a significant contribution to the intellectual development of human, national and cultural values of Cathedral Ukraine. The Academy's achievements in teaching, research and publishing industry reflects the opinion of the Ukrainian scientists about knowledge as a factor of social and economic welfare of the people and the deepening impact on the development of national consciousness, the struggle of Ukrainians for independence. The research of historical experience is a prerequisite for an effective search for further ways of developing Ukrainian higher education in the context of European integration.

The analysis of sources and recent researches. O. Benchak, A. Kostenko analyzed the essence of social knowledge of borders and transborder processes in socio-humanitarian sciences, identified the stages of formation of knowledge about these processes (Benchak, 2018; Kostenko, 2018). N. Polovaia investigated the peculiarities of the development of the system of higher education, which is regarded as one of the most important factors of co-production, which is closely linked with the concept of the information society (Polovaja, 2018). O. Utkin 
summed up certain issues of the organization and activities of the Ukrainian Academy of Economics in the Podebrady, but the researcher did not make a comprehensive analysis of the contribution of its scientists to the development of agrarian science (Utkin, 2015).

The publication's purpose is to highlight the main historical stages of organization Ukrainian Economic Academy, its activities, structure and contribution to the development of agricultural science.

Statement of the basic material. After the defeat of the Ukrainian liberation movement in the 1917 - 1920, a part of the Ukrainian population who fought for the creation of an independent state left the homeland, emigrating to the West. Having been in an overseas environment, imperfectly possessing a foreign language, without knowing the traditions and existing laws, Ukrainians united into the organization «Self-help» and other structures that served their vital needs, supported the national team, opposed denationalization.

Cultural and educational, scientific and technical institutions which had research centres and educational institutions, trained educated personnel rising on the traditions of Ukrainian free science and patriotism, contributed to the revival of the Ukrainian nation. One of such centres was the Ukrainian Economic Academy founded in 1922 in Czechoslovakia in city Podebrady. The Academy trained young, nationally conscious Ukrainians who were abroad to take an active part in the future economic rehabilitation of Ukraine, gathered together intellectuals, studied on the best examples of European science and practice (Ukrajinsjka ghospodarsjka akademija v Chekhoslovacjkij respublici, 1928, pp. 5, 7).

The Academy was organized in difficult period after the First World War. The general political and economic situation in Czechoslovakia during the interwar period as a basis for the establishment of the Ukrainian Economic Academy was characterized in details by S. Vidnyansky, he has gave a positive assessment of its activities (Vidnjansjkyj, 1997, pp. 44-48).

To perform such diverse tasks of a professional, educational and national-patriotic character in a foreign country whose population participated in the First World War as part of the Austro-Hungarian Army, could only be a high school of polytechnic type. The Ukrainian National Higher School with such tasks, the teaching staff, student community and teaching language was created with the assistance of the Ukrainian Public Committee in Prague, headed by M.Yu.Shapoval. On January 17, 1922, the general meeting of this committee elected a special organizational committee, which took care of the assistance to Ukrainian scientists and cultural forces in Ukraine, the rescue of cultural forces in emigration through their use in cultural and educational work, the preparation of Ukrainian young intellectuals, and specialists in the economic and technical sectors. The beginning of the functioning of the educational establishment was April 22, 1922, when its first professorial council took place, although the statute of Academy was approved on May 16 this year. The Academy was located in the ancient castle of the Czech King Yuri Podebrady in Podebrady (CSAHAA of Ukraine, f. 3795, d. 1, c. 128, pp. 12-14).

In organizational matters, the Academy was subordinated to the Ministry of Agriculture. The Ministry of Foreign Affairs of Czechoslovakia was involved in its financial support, and at its expense the Academy was held and scholarships were provided to students. Part of money for the acquisition of training devices was provided by the Ministry of Agriculture. The financial compensation of Czechoslovakia was provided annually by the League of Nations to help emigrants from the former Russian Empire. For the full-fledged activity of the educational institution, provision of the educational process, creation of new structures of these funds was not enough. Therefore, the administration, the teaching staff has made a lot 
of effort and resourcefulness for the development of the institution, gaining authority in the emigrant environment and the civil society of the country.

From the first years of existence, the higher school had a three-year term of studying students, later - four years. According to the statute, the main role in the life of the institution was played by the professorial council, which included the rector, vice-rector and secretary of the council. This council included the right of deciding the voice of all professors and assistant professors who headed the departments. Faculty affairs were decided by the faculty's professorial council. Professors and associate professors of its faculty had the right to decisively vote in the professorial council of the faculty. Control functions in the activities of various structures of the Academy belonged to the Audit Commission, which was directly subordinated to the professorial council of the educational institution. The Academic Council chose the rector, vice rector, secretary and audit committee. The faculty council chose deans, vice deans and secretaries of the faculties. The responsible faculty members were approved by the professorial council of Academy (Ukrajinsjka ghospodarsjka akademija v Chekhoslovacjkij respublici, 1928, pp. 22-28).

The cultural-educational and educational process consisted of the academic year, which was divided into the winter semester from September 1 to March 1 and the summer semester from March 1 to September 1. Teaching different disciplines started annually on October 1 and ended on June 30th. After the first four semesters and the implementation of the planned practical tasks, the students passed the first semicircular exam at a faculty commission, and after completing the full course and performing planned practical exercises, they passed a second semicircular exam. After each exam, the student received a certificate stating his success. Students who passed both semicircular exams and completed the diploma project or wrote a diploma work were allowed to pass the diploma exam.

Graduate examinations were passed at special commissions elected by the faculty professor councils. After the successful completion of the exam, the students received a diploma and an engineer's title with the application of the title of the specialty. All persons who received the title of engineer at Academy or another appropriate special school were allowed to pass the exam and defend the thesis on the title of doctor of the tangible field of knowledge (CSAFU, f. 3 , d. 1, c. 48 , p. 24).

The use of domestic and best foreign methods of teaching different disciplines, successfully planned practice combined with the acquired theoretical knowledge that developed and implemented the teaching staff of the Academy, formed its ranking, attracted young people to join the Ukrainian higher education and communicate with well-known professors and associate professors from Ukraine and Czechoslovakia. During the 1922 - 1932118 teachers worked at the Ukrainian polytechnic school. The pedagogical team consisted of professors, associate professors, lecturers, assistants, auxiliary scientific and technical workers.

On the basis of the order of the Ministry of Agriculture established on April 9, 1920, the Academy consisted of three departments: Agronomic-Forestry with Agronomic and Forestry departments; Economic-Cooperative with Economic, Cooperative and Statistical departments; Engineering with departments of Hydrotechnical, Chemico-Technological. The Economic Department of the Economic-Cooperative Faculty was divided into subdivisions: banking, consular, local self-government and industry (Vynar, B., 1965, pp. 42-48). The Cooperative Department of the Academy was the first high-tech cooperative school in the world. The specific scientific directions, the specialization of future specialists, their positive attitude to the chosen specialty in the process of training were developed by the teachers of the departments. For this purpose, the Agronomy-Forestry Faculty had 19 departments. 
The multifaceted tasks were addressed to the teachers of 20 departments of the EconomicCooperative Faculty. Engineering Faculty consisted of 20 departments. The presence of 59 departments of the Academy, a set of educational disciplines, their filling, the term of study and its organization positively characterized the educational and scientific complex, which acted like western European higher schools (Ukrajinsjka ghospodarsjka akademija $\mathrm{V}$ Chekhoslovacjkij respublici, 1928, pp. 12-14).

The Academy adhered to the principles of rigorous scientific training for students, the promotion of self-education, and the study of literature on various disciplines. First, applied science was considered as «free science», which contributed to the expansion of scientific and theoretical knowledge and practical skills of graduates. Secondly, the educational process was directed as a skilful and flexible combination of practical classes in laboratories, cabinets with industrial practices in cooperatives, agricultural and forestry enterprises, banking institutions and industrial facilities. Thirdly, curricula at all faculties were formed in such a way that there was a permanent balance between scientific disciplines and practical exercises that would contribute to humanitarian, aesthetic education, development of creative abilities. For students of all faculties there was a certain set of humanities, natural sciences and technical disciplines, which gave the opportunity to form specialists capable of performing their duties or to manage some unit or institution. An important principle of teaching the students of the Academy was a combination of theoretical knowledge at lectures with practical seminars, explanations of complex situations, specific student reports (Ukrajinsjka ghospodarsjka akademija v Chekhoslovacjkij respublici, 1928, pp. 6-8).

On the whole, it contributed to the accumulation of scientific knowledge on the specialization of students and the formation of a human person. Programs of scientific disciplines envisaged a broad general scope of major social and special sciences. Each discipline was taught independently, separated from other scientific subjects. In most cases, training was accompanied by practice at industrial enterprises, organizations, and institutions. For each discipline, students received complete knowledge at the level of contemporary scientific achievements. In the third-fourth year, teachers focused on specialization.

The bulk of students joined the Students Community of the Ukrainian Economic Academy of and the Ukrainian Academic Community. In the statute of the Academy it was noted that the community in common efforts supports the organization of student life, raising the intellectual level of all students, the national and cultural development of Ukrainian emigrants, bringing the maximum contributions to the treasury of Ukrainian culture. An important task was to improve the material situation of students on the basis of assistance and self-help.

Organization Ukrainian Economic Academy anticipated that its students would not take an active part in the political life of the Ukrainian Diaspora, in spite of the purposeful educational process. Thus, in December 1922, the leaders of the Ukrainian Academic Community organized a general extraordinary meeting in which the students protested against the separation of the Academy from the Ukrainian Public Committee, believing this as a negative phenomenon for an educational establishment breaking national-cultural forces in a foreign country. The speech of the students of Academy in this case was pointless, since its autonomy was guaranteed by the status, and the performance without awareness of its administration was gaining political character. In the minutes of these extraordinary meetings they wrote that, wanting to eliminate all policies of academic life, we protested against attempts to involve students in political combinations that adversely affect academic life (Ukrajinsjka ghospodarsjka akademija v Chekhoslovacjkij respublici, 1928, pp. 26-28). 
Despite such statements, there were separate attempts to politicize students and therefore the leadership of the academic community openly stated that their organization is not engaged in political activities. Such requirements were the decision of the Czechoslovak government «Russian Assistance Action» (1921), in which the Ministry of Foreign Affairs recommended creating the necessary conditions for Russian and Ukrainian emigrants in order to engage in fruitful work and become real members of the community.

The student community of the Academy throughout its existence, feeling the influence of the Czech environment, life and livelihood of the indigenous population, developed on the basis of national spiritual and cultural values, the use of the best works of Ukrainian literature and art, folk songs, marches, symbols, traditions. Science and other manifestations of spirituality contributed to the fact that foreign Ukrainians largely preserved their national identity, their native language, culture, ceremonies and customs, and religion. All culturalmass work was directed at the formation of national consciousness (Piskun, 2005, p. 54).

As a teaching and research structure, the Ukrainian Economic Academy is characterized by the intensive publishing activity of the teaching staff, in particular the preparation of new textbooks, monographs, scientific collections, participation in international scientific forums, congresses, conferences, symposiums. During the period of the Academy's existence, 698 scientific works were published, mainly textbooks for students. Most of them were issued in lithograph printing in the amount of $50-150$ copies. Textbooks on narrow-branch disciplines were printed on a typewriter in the amount of $6-8$ copies. In total, they gave over 200 new Ukrainian textbooks. «Ukrainian Publishing Society at the Ukrainian Academy of Economics», founded in 1922 by professors and students, and its various organizations have published 245 editions to the beginning of 1928 (Svjato Podebradsjkoji akademiji, 1932, pp. 26-27).

In the department of agronomy, their researches were published by P. Y. Andreevsky, K. M. Matsievich, I. P. Mazep, V. M. Chereediev, I. S. Sheremetiensky, V. M. Domanitsky, J. O. Rusov, K. I. Osaulenko, K. I. Mihayliuk and others. Problems of forestry were considered in publications by B. G. Ivanitsky, M. S. Kosyuri, O. I. Petriv, O. Kolubaiva, V. Proudi, K. Podolyana. The fourth part of Academy books was published in Czech, German, French, English, Spanish and Serbian. Achievements of Ukrainian organizations in the field of science and education showed their intellectual level, successful long-term searches and finds of ways and motives for mobilizing the scientific forces of emigration expressed in democratic forms of effective activity.

A remarkable phenomenon of scientific life of the Academy was research by the famous scientist, theorist of cooperation, Professor B. Martos «Theory of Co-operation», who has analyzed the socio-economic causes of the formation of cooperatives, its role in economic life (Martos, 1923, pp. 22-42). The formation of the idea of cooperation, its development was substantiated in the fundamental monograph by Professor S. Borodayevsky «History of Cooperation» (Borodajevsjkyj, 1925).

The integration of Ukrainians in the scientific, educational and social environment of foreign countries was facilitated by the preliminary international cooperation with scientist structures, the loyal attitude of government officials to the implementation of some proposals by leaders of emigrant groups, the activities of Ukrainian researchers, political figures in authoritative international associations that sympathized with the Ukrainian the community. Creative cooperation between higher educational establishments, research institutions, societies required the creation of specialized organizations to strengthen international scientific cooperation, implementation of plans for the development of education, science and culture of emigrant 
communities (Vytanovych, I., 1964, pp. 224-234). First of all, such a form of cooperation was the Ukrainian Academic Committee, created in 1924 on the proposal of the Historical Philology Society at the Ukrainian University in Prague (Shuljghin, 1926, pp. 11-12).

In early 1925, the Institute for Intellectual Cooperation at the League of Nations, at the initiative of Ukrainians at the session, discussed the issue of official recognition of the Ukrainian Academic Committee. At the League of Nations, on May 18, 1925, the Academic Society of Ukrainian Professors and Students was formed in Podebrady. As full members of the International University federation, its members disseminated the ideas of the League of Nations and maintained business contacts with international organizations (Narizhnyj, 1942, pp. 66-68).

Scientists from the Ukrainian Diaspora took an active part in the work of the International Congress of Slavic Botanists, the International Agrarian Congress, the International Crop Growing Congress and the International Congress of Foresters. The Ukrainian Academic Committee was one of the organizers of the 1 st and 2 nd scientific congresses. In particular, the 1st Ukrainian Scientific Congress was held on October 3-7, 1926 in Prague (Ukrajinsjkyj inzhener, 1932, p. 55). Its delegates were 1,400 people, including professors of the Ukrainian Economic Academy, the Ukrainian Pedagogical Institute, the Ukrainian University of Prague, as well as scientists from Germany, France, Poland, Romania, Belgium, Galicia (Shuljghin, 1926, pp. 11-12).

In 1928 Ukrainian foresters united the Czech Forestry Union, whose members, developing Ukrainian forestry school, studied in detail the scientific and practical issues of forestry in foreign countries, became acquainted with the latest achievements of scientists in the industry in the world. Despite the successful scientific and educational work of the Ukrainian high school, in connection with the economic crisis, a decrease in funding, the Academy gradually ceased its activities. Officially it was liquidated in accordance with the decision of the Council of Ministers of Czechoslovakia of December 31, 1935 and the order of the Ministry of Agriculture of January 1, 1936. The successor of the Academy became the Ukrainian Technical and Economic Institute in the Podebrady, which continued its activity as a correspondence higher technical school (CSAHAA of Ukraine, f. 3563, d. 1, c. 117, pp. 18-22).

Conclusions. The Ukrainian Economic Academy underwent a difficult period of formation, reformation and stable development, received the appropriate material and technical base, a qualified professorial teaching staff, a significant number of students, that became a guarantee of positive results in the training of highly educated professionals, research and publishing industries. This higher polytechnic school became a significant element of the spiritual unity of Ukrainian society, an indicator of the maturity of Ukrainian science, education and culture. The professorial teaching staff considered knowledge as a factor of socio-economic growth of the welfare of the people and confirmation of the tendency to increase the influence of scientific, educational and national-cultural potential on the deepening and consolidation of national consciousness, public organization and the activity of Ukrainians in the development of the struggle for the independence of the Motherland.

The upbringing of future specialists was aimed at building a new Ukrainian state, serving for the interests of the nation and society. Democratic methods of activity of the Ukrainian higher educational institution characterized the ability of its leadership to take into account the thoughts and wishes of the members of the labour collective, use the latest achievements of science and technology, to cooperate mutually with various scientific and publishing organizations of Europe and America. It contributed to the efficiency of Academy, in particular the high level of training, which, in their knowledge and skills, did not yield to graduates of universities in the West, successfully worked in various fields of the economy. Achievements 
of the educational and research complex increased his credibility in the international arena and showed that Ukrainian science abroad was an honourable place.

Acknowledgments. Sincere thanks to the director of the National Scientific Agricultural Library of National Academy of Agrarian Sciences of Ukraine, Verhunov Viktor.

Funding. The author received no financial support for the research, authorship, and/or publication of this article.

\section{BIBLIOGRAPHY}

Benchak, O. F. (2018). Problematyka kordoniv i transkordonnykh procesiv u socioghumanitarnykh naukakh [Problems of Borders and Cross-Border Processes in Socio-Human Sciences]. Ghrani, 21(1), 62-69. doi: 10.15421/1718153. [in Ukrainian].

Borodajevsjkyj, S. V. (1925). Istorija kooperaciji [History of co-operation], Pragha, 446 p. [in Ukrainian].

Centraljnyj derzhavnyj arkhiv vyshhykh orghaniv vlady i upravlinnja Ukrajiny [Central State Archives of the Higher Authorities and Administration of Ukraine - CSAHAA of Ukraine] [in Ukrainian].

Centraljnyj derzhavnyj arkhiv zarubizhnoji ukrajiniky [CSAFU - Central State Archive of Foreign Ucrainica-CSAFU] [in Ukrainian].

Kostenko, A. M. (2018). Informacijno-komunikatyvni strateghiji jevrointeghraciji v Ukrajini [Information and communication strategies of eurointegration in Ukraine]. Ghrani. 21(1). 70-77. doi: 10.15421/1718154. [in Ukrainian].

Martos, B. (1923). Teorija kooperaciji [Theory of co-operation], Podjebrady, 246 p. [in Ukrainian].

Narizhnyj, M. (1942). Ukrajinsjka emighracija. Kuljturna pracja mizh dvoma svitovymy vijnamy [Ukrainian emigration. Cultural work between two world wars]. (Vol. 1). Pragha, 250 p. [in Ukrainian].

Piskun, V. (2005). Motyvacija rozbudovy merezhi naukovykh ustanov ukrajinsjkoju politychnoju emighracijeju u 20-kh rr. XX st. [Motivation to build a network of scientific institutions in Ukrainian political emigration in the 20's of the 20th century]. Naukovi zapysky. Ostrogh - Toronto - New-York, (5), 51-64. [in Ukrainian].

Polovaja, N. O. (2018). Bezperervna osvita jak vektor rozvytku informacijnogho suspiljstva [Continuing education as a vector of the development of the information society]. Ghrani, 21(4), 91-96. doi: 10.15421/171862. [in Ukrainian].

Shuljghin, O. (1926). Ukrajinsjkyj naukovyj z'jizd za kordonom [Ukrainian Scientific Congress Abroad]. Tryzub. Paryzh, 18 zhovtnja, 11-13. [in Ukrainian].

Svjato Podebradsjkoji akademiji, (1932). Svjato Podebradsjkoji akademiji. 1922 - 1932 [Holiday of Podebrady Academy. 1922 - 1932]. Podebrady, 32 p. [in Ukrainian].

Ukrajinsjka ghospodarsjka akademija v Chekhoslovacjkij respublici, (1928). Ukrajinsjka ghospodarsjka akademija v Chekhoslovacjkij respublici [Ukrainian Economic Academy in the Czechoslovak Republic]. Podebrady, 64 p. [in Ukrainian].

Ukrajinsjkyj inzhener, (1932). Ukrajinsjkyj inzhener [Ukrainian engineer]. Tekhnichni i ekonomichni nauky na II Ukrajinsjkomu naukovomu z jizdi v Prazi, Podebrady, (4), 55-56. [in Ukrainian].

Utkin, O. I. (2015). Ukrajinsjka ghospodarsjka akademija v Chekhoslovachchyni: stvorennja ta dijaljnistj [Ukrainian Academy of Economics in Czechoslovakia: creation and activities]. Istorija nauky i bioghrafistyka. URL: http://inb.dnsgb.com.ua/2015-1/15.pdf [in Ukrainian].

Vidnjansjkyj, S. V. (1997). Ukrajinsjke pytannja v zovnishnjopolitychnykh koncepcijakh Chekhoslovachchyny (1918 - 1989 rr.) [The Ukrainian issue in the foreign policy concepts of Czechoslovakia (1918 - 1989]. Ukrajinsjkyj istorychnyj zhurnal, 1. URL: http://resource.history.orgh.ua/publ/ journal_1997_1_43. [in Ukrainian].

Vynar, B. (1965). Materijaly do istoriji ekonomichnykh doslidiv na emighraciji (1919 - 1964) [Materials to the history of economic experiments on emigration (1919-1964)], Mjunkhen, $120 \mathrm{p}$.

Vytanovych, I. (1964). Istorija ukrajinsjkogho kooperatyvnogho rukhu [History of the Ukrainian cooperative movement], New-York, 624 p. [in Ukrainian].

The article was received on February 20, 2019. Article recommended for publishing 27/08/2019. 